\title{
Mülteci Çocukların Çizdiği Resimler Yardımıyla Okula Uyum Durumlarının İncelenmesi
}

Araştırma Makalesi / Research Article

D Rıdvan KARABULUT, Ahi Evran Üniversitesi (iD Nurdan KASAPOĞLU, Ahi Evran Üniversitesi DEnver TÜRKSOY, Ahi Evran Üniversitesi (iDHilal KIRAT, Ahi Evran Üniversitesi

$\overline{O ̈ z}$

Bu çalışma göç etmek zorunda bırakılan Afgan kökenli çocukların uyum durumlarına göre yaşadıkları sorunları ve bu sorunları mülteci öğrencilerin çizdiği resimler yardımıyla okula uyum durumlarının incelenmesini amaçlamaktadır. İnsanlar tarih boyunca farklı nedenlerden dolayı göç etmek zorunda bırakılmıştır. Afganistan'da yaşanan sorunlar ve halkın daha iyi yaşam koşullarını elde etme çabaları Afgan halkını göç etmeye zorlamıştır. Bu yüzden göç en çok çocukları etkilemiştir. Afganistan'dan Türkiye’ye göç eden mültecilerin en temel nedenleri; işsizlikten kaynaklı bir dizi ekonomik problemlerin yanı sıra, ülkede güvenli bir ortamın hâkim olmayışı, göçün yaşanmasında önemli faktörlerdendir. Araştırma Türkiye'nin Kırşehir ilinde gerçekleştirilmiştir. Araştırmanın katılımcıları 2017-2018 eğitim öğretim yllında Kırşehir ili Merkez İlçesinde öğrenim gören 3-6 yaş grubu 24 okul öncesi öğrencisi ile gerçekleştirilmiştir. Mülteci öğrencilerin çizmiş oldukları resimler sonucunda öğrencilerin resimleri yaparken karamsarlık ve korkuları temsil eden renklerin ağırlıkta kullanıldığı görülmüştür. Bu durumun çocukların çoğunun iç dünyalannda karmaşalar ve korkular yaşadıklarını gösterdiği söylenebilir. Resimlerde, çocukların tamamına yakını yalnızca kendilerini çizmiş olup bu durum kendilerini dış dünyadan soyutladıklarını gösterdiği söylenebilir.
Anahtar Kelimeler

Mülteci çocuk, okul öncesi, resim yorumlama, okula uyum, içerik analizi, mülteci çocuk.

Makale Hakkında

Gönderim Tarihi: 04.06.2020

Kabul Tarihi: 27.10.2020

E-Yayın Tarihi:

25.12.2020

Examination of The Adaptation Status Of The Refugeestudents With The Help of The Drawing
Keywords
Abstract
This study aims to examine the problems of Afghan students who were forced to
migrate and their adaptation to the school with the help of the pictures drawn by the
refugee students. Throughout history people have been forced to migrate for different
reasons. The problems in Afghanistan and the efforts of the people to achieve better
living conditions have forced the Afghan people to emigrate. That's why migration has
affected most of the children. The main reasons for the refugees migrating from

Afghanistan to Turkey; in addition to a number of economic problems caused by unemployment, the lack of a safe environment in the country is an important factor in the migration. The research was carried out in Kurşehir Province of Turkey. The sample includes 48 Afghan refugee students from the 3-6 age group who study in kırşehir Province central district in 2017-2018 academic year. It was carried out with 24 preschool students. As a result of the pictures drawn by the refugee students, a number of problems such as confidence problems, dominance, perfectionism, closeness, anger and happiness have emerged by looking at the age and developmental levels of preschool refugee children.
Article Info

Received: 06.04.2020

Accepted: 10.27.2020

Online Published: 12.25.2020 


\section{Giriş}

Ülkemiz coğrafi ve jeopolitik konumundan dolayı sınırı bulunduğu birtakım Ortadoğu ülkeleri ile komşudur. Özellikle bu komşu ülkelerden; Irak ve Suriye'de iç savaş, bölgesel, 1rksal, dini, politik ve ekonomik sorunlar yaşamaktadır (Bekirvd, 2016).

Çoklukla ülkeler zulüm ve şiddetin maruz kalan nüfusla karşı karşıya gelmiş ve buradaki insanlar, özgürlüklerine ve yaşamlarına yöneltilen tehditlerden kaçma yolunu seçmişler buna karşın hükümetler insani yükümlülükler, siyasi gerçekler ve bunula birlikte ulusal ihtiyaçları konusunda uğraşı göstermişlerdir (Jastram ve Achiron, 2001 Akt: Kolukırrk, 2014). Ansen (2012) Anadolu topraklarının asırlardır farklı milletlerden koruma arayan insanlar için bir sığınma bölgesi olduğunu, Türkiye'nin özellikle 1980’lerden sonra komşu ülkelerde meydana gelen olaylar nedeniyle toplu sığınmalarla karşı karşıya kaldığını ve Ortadoğu'da yaşanan iç karışıklıkların Türkiye'ye daha çok kişinin sığınmasına neden olarak iltica konusunda ülkemizin hedef ülke haline geldiğini belirtmiştir (Gültekin, 2016).

İnsanların, doğdukları yerden başka yerlere geçici ya da sürekli olmak üzere taşınmasına göç, bir ülkeden diğer ülkeye yapılan göçlere ise dış göç denilmektedir. Ekonomik nedenler, çalışmaya gidilmesi, tabii afetler, savaşlar, etnik nedenler, sınırların değişmesi, uluslararası anlaşmalarla sağlanan nüfus değişimi insanları göçe zorlamaktadır (Demirkan, 2011). Göç başlı başına bir olumsuzluk içermektedir. Resim etkinlikleri okulöncesi dönemde bu nedenle çok önemlidir (Memiş, 2014).

Göç etmek zorunda kalan çocukların göç ettikleri ülkede birçok olumsuzlukla karşlaştığı bilinmektedir. Çünkü yeni bir ortama uyum sağlamak, dil farkllıkları gibi nedenler çocukları etkilemektedir. Bu durumla karşı karşıya kalan çocukların iç dünyalarını anlamada en etkili yol resimdir. Resim ile kendini anlatan, sorunlan ile ilgili bize ipuçlanı veren çocuklanı bulmak, sorunlarnn çözümü ile ilgili çocuğa yardımcı olmak mümkündür(Swell,2011).

Farklı dil ve kültüre sahip bir ülkeye göç etmek zorunda kalan çocukların durumunu anlamak için kullanılacak en evrensel araçlardan biri de resimdir. Çocuğun çizdiği resimler sadece onun yeni bir ürün ortaya çıkarması değil, kendi hakkında önemli ipuçları vermesine yardımcı olacaktır (Savaş, 2014).yalnız çocuğun yaptığı resim etkinliğini bir teşhis malzemesi olarak değil, çocuğun iç dünyasından gereksinimlerin kaynağına eğilmemizi sağlayacak önemli bir iletişim aracı olarak ele almak gerekir (Kutluer,2015). Resmin çocuk için anlamı ise içsel gerçekliğin kağıt aracıllğıyla dışsal gerçekliğe dönüşmesidir. (Atasoy, 2016).

Çocukları duygusal olarak etkileyen olayları aktarmada sözel ifadeden daha etkili bir yoldur. Gross ve Haynes (1998) resmin çocuklarla sözlü iletişimi kolaylaştırıp kolaylaştırmadı̆̆ını bulmak için bir dizi çalışma yürütmüştür, resim çizmenin çocukların iletişim becerilerini, duygularını ve algılarını arttırdığını bulmuşlardır. Resim çocuklar için kendilerini ifade etme biçimidir. Burada önemli olan görsel olarak yansıtılan konunun ne ifade ettiğidir. Çocuklar duygularını, hayallerini resim yaparak açığa vururlar, diğer bir tabirle resim çocuğun içselliğini, simgelerle nesnel dünyaya kopyalama sürecidir. Çocuk kullandığı renklerle, çizdiği çizgilerle iç dünyasını kağıda yansıtır. Çocuklar resim çizerken kendilerine özgü ifadeler ile çizim yapmakta ve farklı yönlerini gösterebilmektedir. Çocuk resimlerini analiz etmede kullanılan yöntemlerden biride resim yorumlamadır. Resim yorumlamanın amacı ebeveynde/ öğretmende şüphe, kayg1 oluşturmak değil, çocuğun iç dünyasına yolculuk yapmaktır. Resim yorumlamada öncelikli olarak çocuğa yaptığı resimde ne yaptığının yorumlatılmasıdır. Çocuğun verdiği cevaplar kaydedilerek hemen resmin yorumlanması gerekir. Çünkü uzmanın gözlemleri kaydedilen yorumları unutmadan kayıt altna alınarak resim yorumlama ile ilgili kriterler göz önünde bulundurularak resim yorumlama yapılmalıdır. Resim; çocuğun sorunlarına, güçlü ya da rahatsız edici deneyimlerine dair veri sağlamasının yanı sıra çocukların kendileri, çevreleri hakkındaki duygu ve düşüncelerini, algılarını ve gözlemlerini paylaşma firsatı sağlar. Resim çizdirme yolu ile elde edilen veriler uzmanlar tarafindan; çocuklardan sorunlarını belirleme, gelişim düzeyine uygun iletişim kurma ve uygun yaklaşımda bulunmak için kullanılabilir.

Göç etmek zorunda kalan yanısıması olarak kabul edilmekte ve bireylerin iç dünyası hakkında ayrıntılı bilgi vermektedir (Halmatov, 2018). Afgan kökenli öğrencilerin, yapmış oldukları resimler 
yardımıyla kendilerini okula ait hissetme durumlarının ve sosyalleşmelerinin belirlenmesini amaçlamaktadır.

\section{Yöntem}

\section{Araştırma Deseni}

Nitel araştırma desenlerinden biri olan fenomenolojik yöntem kullanılmıştır. Grup ya da insanların tecrübe ve bakış açlarına dayanarak detaylı bir şekilde incelenmesidir. (Hammersley,2013; Patton, 2003; Yin,2011). Araştırma veri resimlerle toplanacaktır. Öğrenciler resimleri çizerken yaşantılarını yansıtacaklarının düşünülmesi ve bir görsel sanat olan resimlerin bireyleri yansıtacağı düşüncesi ile bu yönteme başvurulmuştur. Çizilen resim ile resmi çizen kişinin ruh hali arasında bir etkileşimin olduğu birçok uzman tarafından ileri sürülmüştür (halmatov,2016). Goodman ve Sully gibi araştırmacılar çocuğun resimlerinde objenin sembolik yansıtmasını resmettiğini belirtir. Aynı şekilde çizilen resimler nesnelerin görüntüsünü aktarmayı değil görsel ve duyusal deneyimleri birlikte üreten bir sembol üretmektir. Çizimin amacı çocuğu tatmin edecek bir şekilde sembolize edilmesidir. Bu nedenle çocuk çizimlerinde iç dünyasının onarımı için bir sebep gizlidir (Özlü, 2015). Resim analizi bireylerin yaşantılarını resimler yoluyla aktarmasında bir araç olarak kullandıkları düşüncesiyle bu tasarım benimsenmiştir. $\mathrm{Bu}$ araştırmada mültecilik olgusuna odaklanılmış olmasına karşın çocuklar ile iletişim sorunu olacağ 1 düşünülerek resim analizine gidilmiştir. Ayrıca resim beş resim gelişim döneminden 4-7 yaş aralığını kapsayan şema öncesi dönemin en tipik özelliklerinden biri olan "çocukların saydam resimler çizerek aile bireylerini çizmekten zevk almalarıdır” (Soyupak ve Yalçınkaya, 2020). Araştırma verileri 2017-2018 eğitim-öğretim yllında Kırşehir ili Merkez İlçesinde öğrenim gören, 3-6 yaş grubu mülteci çocukları kapsamaktadır.

\section{Araştırma Katılımcılant}

Araşırıma katılımcıları belirlenirken amaçlı örneklem yöntemlerinden ölçüt örneklem yöntemi temel alınmıştır. Bu araştırmadaki ölçütler ilköğretim düzeyinde Kırşehir ilinde öğrenim gören mülteci kökenli ve Afgan uyruklu olma durumudur. Afgan kökenli öğrencilerin tercih nedeni diğer ülkelerden göç eden öğrencilere kıyasla sayılarının daha fazla olmasıdır. Kırşehir il merkezinde toplam 48 Afgan kökenli mülteci okul öncesi öğrencisi bulunmaktadır. Araştırma katılımcıları ise, bu 48 çocuğun 24’ü dür.

\section{Veri Toplama Arac1}

Veri toplama yöntemi olarak çiz ve anlat tekniği kullanılmıştır. Çiz ve anlat tekniği temelinde bireylere belirlenen bir konu hakkında resim çizmeleri ve sonrasında çizdikleri resimleri anlatmaları temeline dayanmaktadır ((Driessnack, 2006); Klepsch, \& Logie, (1982). Veri toplama arac1 olarak çocuklar için evrensel bir dil olan resim çizim yöntemi tercih edilmiştir. Ayrıca Afgan kökenli öğrencilerin Türkçe dil yapısına hakim olmamalanı kaynaklı kelime dağarcı̆̆ının yetersiz olması nedeniyle kendilerini ifade konusunda sorun yaşayacakları düşüncesidir. Resim görsel imgeleri içeren kültürel unsurlardan bağımsız ve yukarda ifade edildiği gibi evrensel bir dil özelliği taşıması nedeniyle tercih edilmiştir. Çiz ve anlat tekniğinde ilk olarak çocuktan bir konu hakkında resim çizmesi istenir. Daha sonra çizdiği resim hakkında sohbet edilir. Çocuğun gelişimsel durumuna bağlı olarak çizdiği imlerin farklı anlamları bulunduğuna yönelik alan yazında çalısmalara rastlanmaktadır. Çocuk resmi anlatırken alınan notlar sayesinde imge ile ifade etmeye çalıştı̆̆ oldu ilişkilendirilir.

Araşturmada her çocuğa A4 boyutun da resim kağıtları ve pastel boyalar dağttlmıştır. Öğrencilere ‘Bahçe de oyun oynuyoruz' yönergesi verilerek resim yapmaları istenmiştir 15-20 dakika süre verilmiştir.

\section{Veri Toplama Süreci}

Araştırma verileri 2017-2018 eğitim-öğretim yılı bahar döneminde toplanmıştır. Başlangıçta İl MEB'den alınan veriler doğrultusunda okullar ve öğretmenler belirlenmiştir. Öğretmenlerle görüşülmek 
üzere okul müdüründen izin alınıp, ardından uygulama için randevular alınmıştır. Cuma günü sanat etkinliği dersinde tüm öğrencilere "Bahçede oyun oynuyoruz" adlı yönerge verilerek resim yapmaları istenmiştir. Etkinlik yönergesinin anlaşılmama ihtimaline karşın, sınıfta bulunan ve Türkçe bilen bir Afgan kökenli çocuğun yardımı ile diğer Afgan kökenli çocuklara yönerge anlatılmıştır. Bütün çocuklara kâğıt ve boya kalemleri dağıtılmıştır. Masada her renkten olan boya kalemleri yer alarak çocukların istediği boya ve kalemleri kendilerinin tercih etmeleri sağlanmıştır. Çocukların dikkat süreleri kısa olduğu için 15-20 dakika süre verilmiştir. Çizimler bittikten sonra mülteci öğrencilere resimde neler çizdikleri sorulmuştur. Sınıfta Türkçe bilen çok az Afgan mülteci öğrenci vardır, bu öğrenciler çizdikleri resimleri kolayca anlatmıştır; fakat Türkçe bilmeyen çocukların resimlerini ise öğretmenleri ve sınıfında Türkçe bilen Afgan öğrenciler sayesinde resimler açıklanmış ve kağıtların arkasına notlar alınmıştır.

\section{Veri Analizi}

Elde edilen veriler yorumlayıcı içerik analiz yöntemi kullanılarak analiz edilmiştir. yorumlayıcı içerik analizi temel içerik analizi gibi pozitivist bir mantı̆̆a dayanmayıp "ne" "neden" "nasıl" sorularına yanıt arayan, irdeleyici ve betimlemenin ötesinde derin anlamları ortaya koymayı amaçlayan bir analizdir. (Drisko \& Maschi, 2015). Analiz için kullanılacak resimlerde ölçme bir uzman tarafindan gerçekleştirilmektedir. Araştırma temel alındığında veri kaynağı olarak toplanan resimler ve resimlerin yorumlarının bütüncül bir şekilde yorumlanması bir uzmanlık istediği ve bu konuda eğitim alınmış olması gerektiği düşünülmektedir. Toplanan resimler bir resim analiz uzmanı tarafindan ayrıntıll şekilde yorumlanmıştır. Uzman görüşleri doğrultusunda kodlar ve temalar oluşturulmuştur. Analiz sonuçlanı frekans ve yüzde tabloları üzerinden yorumlanmıştır. Yapılan yorumlamalara ait aşağıdaki şekillere yer verilmiştir.

\section{Bulgular}

Araştırma verilerinin yorumlayıcı içerik analizi ile analiz edilmesinin ardından çizilen resim ve belirtilen görüşlerin yorumlanması sonrasında "uzman görüşlerinden" elde edilen kodlar ve temalar bulgular kısmında yer almaktadır. Araştırmada tümevarımsal bir raporlaştırma mantığı güdülmüştür. İlk olarak öğrenci resimleri yorumlanmış daha sonra bulgular özetlenmiştir. Bulgular örneklendirilirken öğrenci isimlerine yer verilmeyip resimler örnek olarak sunulmuştur.

Araştırmada altı ana başlık “tema” belirlenmiştir. Bunlar aşağıda örnekleriyle ifade edilmiştir.

\section{Güven Problemi Olan Resimler}

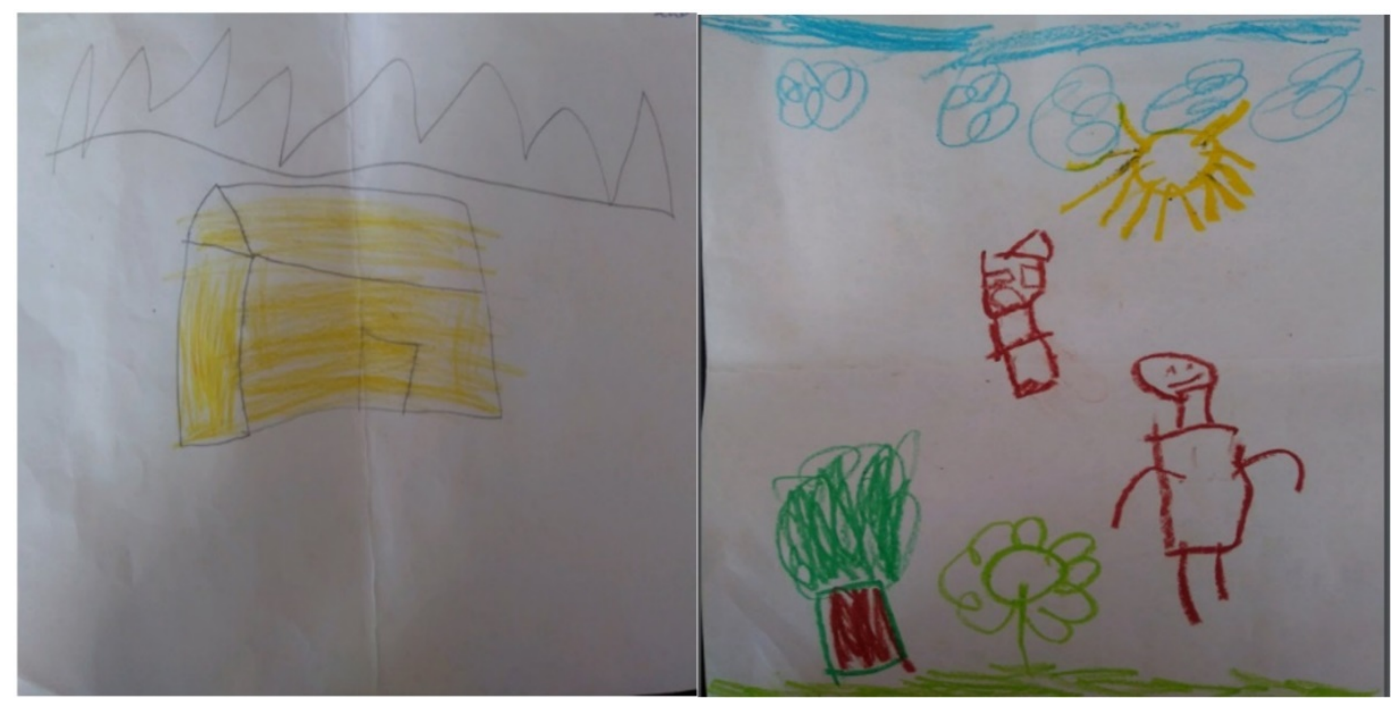

Şekil 1. Güven problemi ile ilgili resimler 
Yukarda çocuklar tarafindan çizilmiş iki resim yer almaktadır. Soldaki resimde çizilen okulda pencereler bulunmamakta ve zemin belirgin değildir. Yapılan analiz sonucunda çocuğun, okulunun pencerelerini çizmeyişi bir güven arayışı içerisinde olduğunu göstermektedir. Bu nedenle çocuğun güven problemi yaşadığı görülmektedir.

Sağdaki resimde ise bir çevre tasviri yapılmıştır. Kullanılan renkler canlı ve çocuğun seviyesine uygundur. Buna karşın çizilen çocuk (öğrencisi olduğunu ifade etmiştir) bütün fiziksel uzuvlara sahip olmasına karşın ayakları yere basmamaktadır. Çocuğun ayaklarının zemine basmaması ve yukarda kalması çocukta güven eksikliğinin göstergesi olarak yorumlanmıştır.

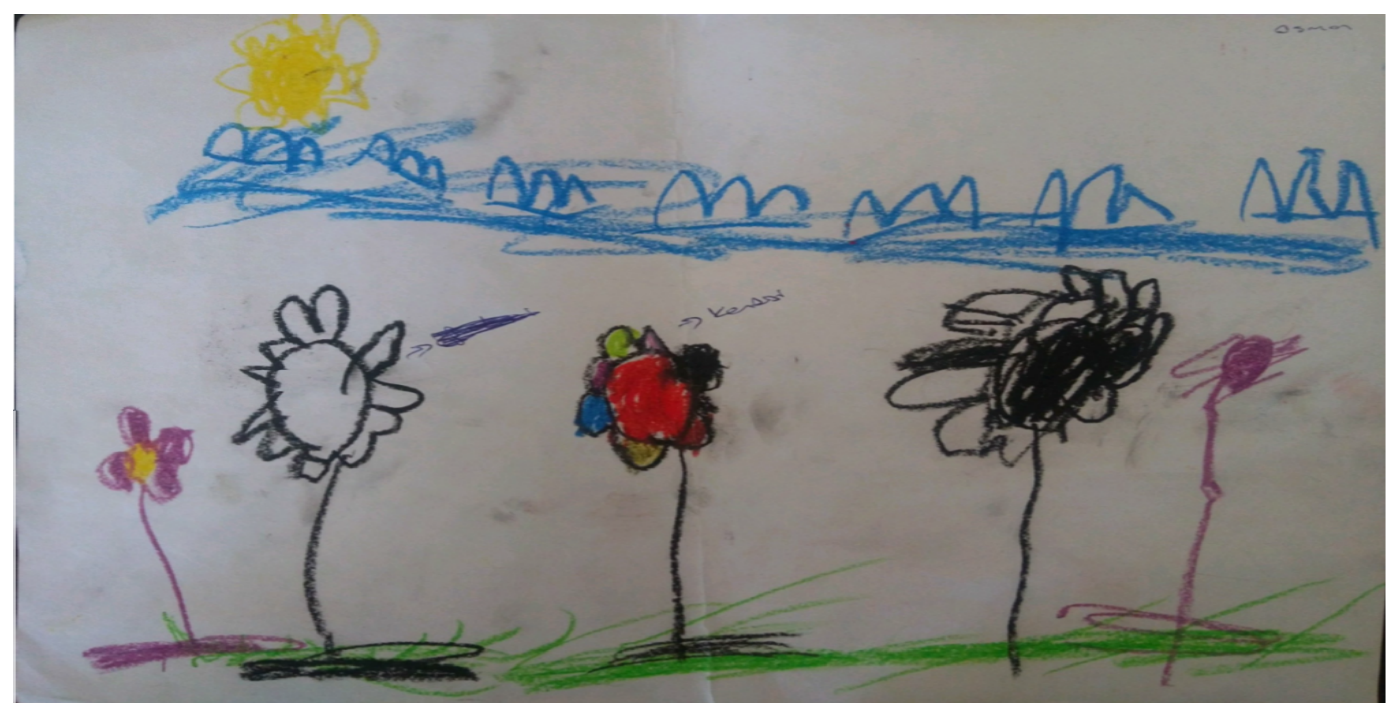

Şekil 2.Arkadaşa yönelik güvensizlik

Şema öncesi dönemde çocuklar kendilerini bir bitki veya hayvan şeklinde çizebilirler. Ortada gördüğümüz rengarenk çizilen çiçek çocuğun kendisidir. Çocuğun diğer çizmiş olduğu çiçeklerde sınıftan arkadaşlarıdır. Kendisiyle beraber 3 çiçek zemine oturtulmuş; fakat sadece aralarından tamamen siyah renge boyanmış olan çiçek zemine oturtulmamıştır ve bu çocuğun arkadaşıyla yaşamış olduğu sorunu ve ona karşı bir güvensizliği olduğunu göstermektedir.

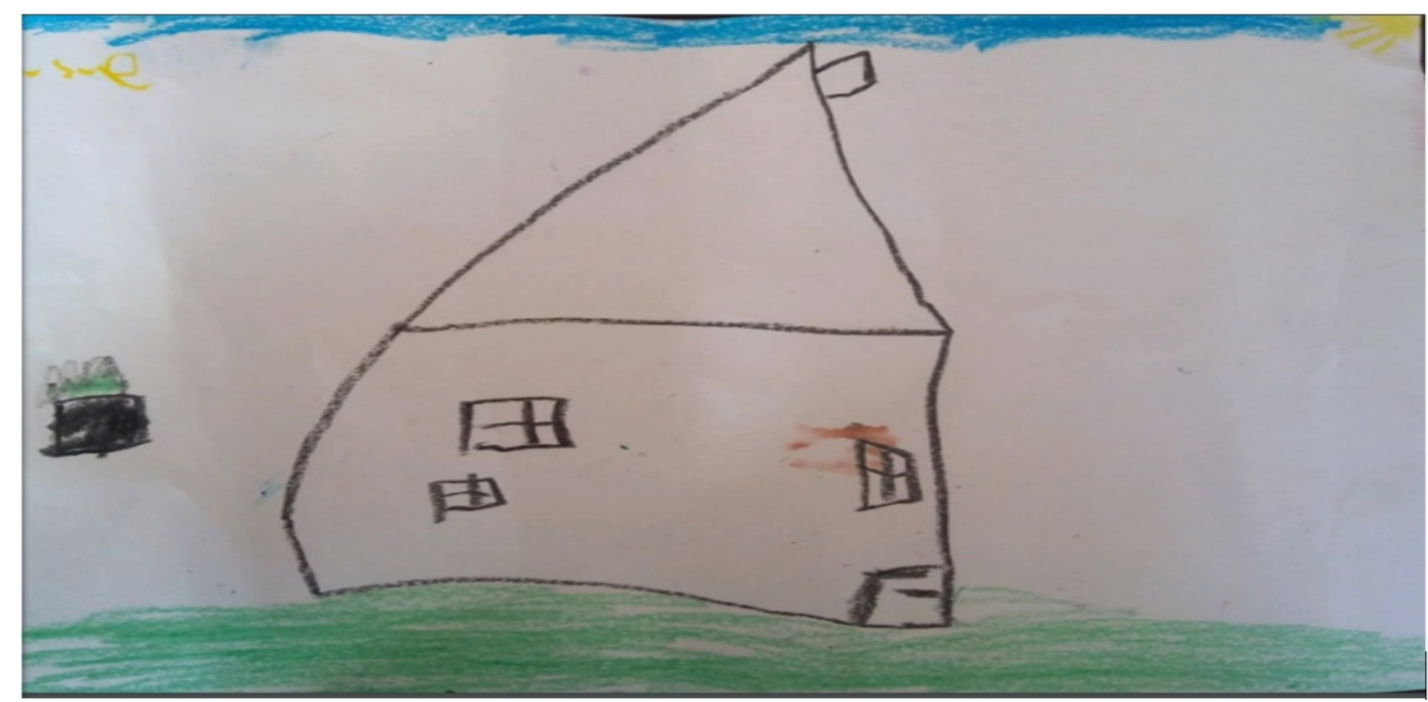

Şekil 3. Güvensizliğin farklı bir göstergesi

$\mathrm{Bu}$ resimde diğer resimlerden farklı olarak binanın pencereleri ve bacası bulunmaktadır. Ayrıca binanın bir zemine oturduğu görülmektedir. Aslında bu zamana kadar çizilen hep ev resimlerinde yaz, kış çocukların bacadan duman çıkarması bazılarına göre ilginç gelebilir, resimde de bir baca var; fakat 
dumansız bir bacanın olması çocuğun yeteri kadar kendisini güvende hissetmediğini ve güven problemi yaşadığını göstergesi olarak değerlendirilmiştir.

\section{Baskinlık (Dominantlı)) Olan Resimler}

Aşağıda öğrencilerin çizimleri ve bu çizimlerde yer alan baskınlık imgeleri detaylandırılarak aktarılmaya çalişılmışır.

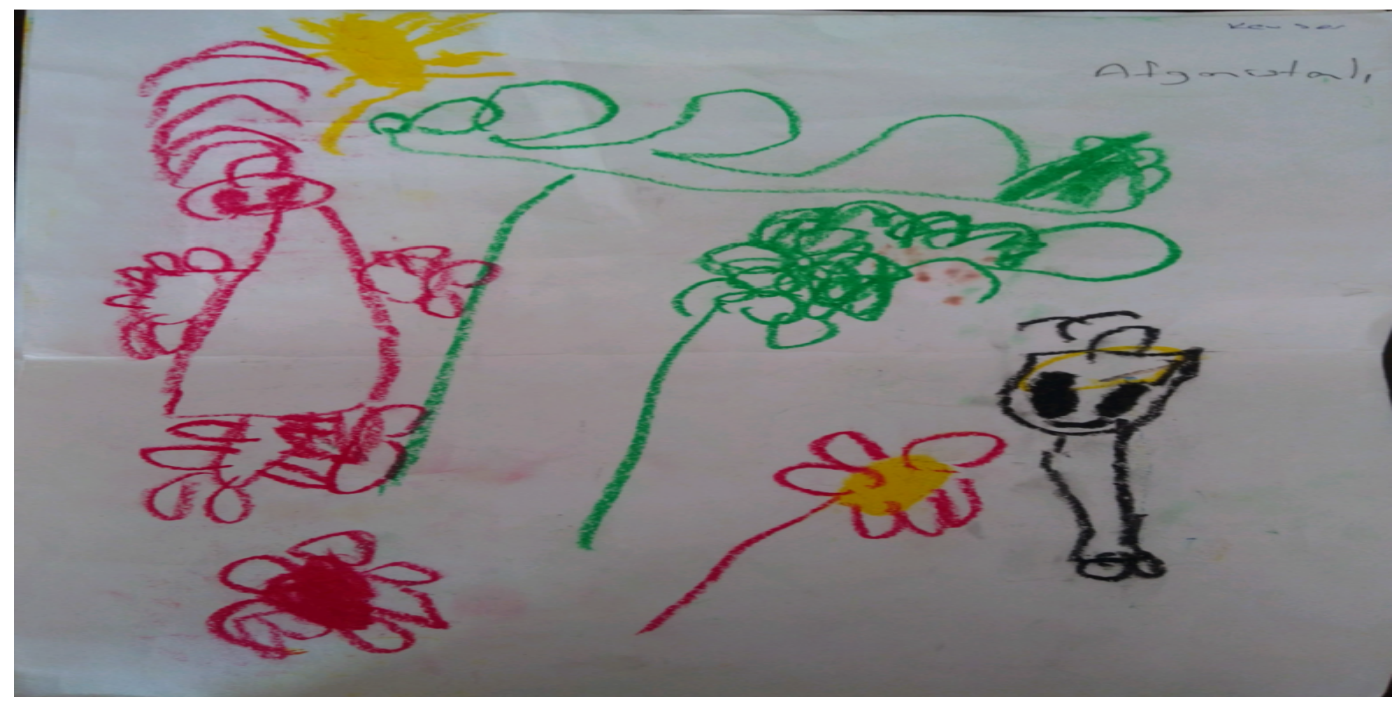

Şekil 4. Baskı altında olmaya yönelik bir resim

$\mathrm{Bu}$ resimde iki tane çocuk vardır, çocuk kendisini kırmızı renkte ve arkadaşını da siyah renkte çizmiştir. Kırmızı renkte çizilen çocuğun el ve ayak parmakları varken, siyah renkte olan çocuğun ellerinin olmayışı, el ve ayak parmaklarının da çizilmeyişi kendisini kırmızı renkte çizen çocuğun dominantlı̆̆1 yani liderlik, üstünlük pozunun kendisinde olduğunu göstermektedir. Bu durum çocuğun çevresinde birileri tarafından bastırıldığı ya da etki alında bırakıldığının göstergesi olarak düşünülmektedir.

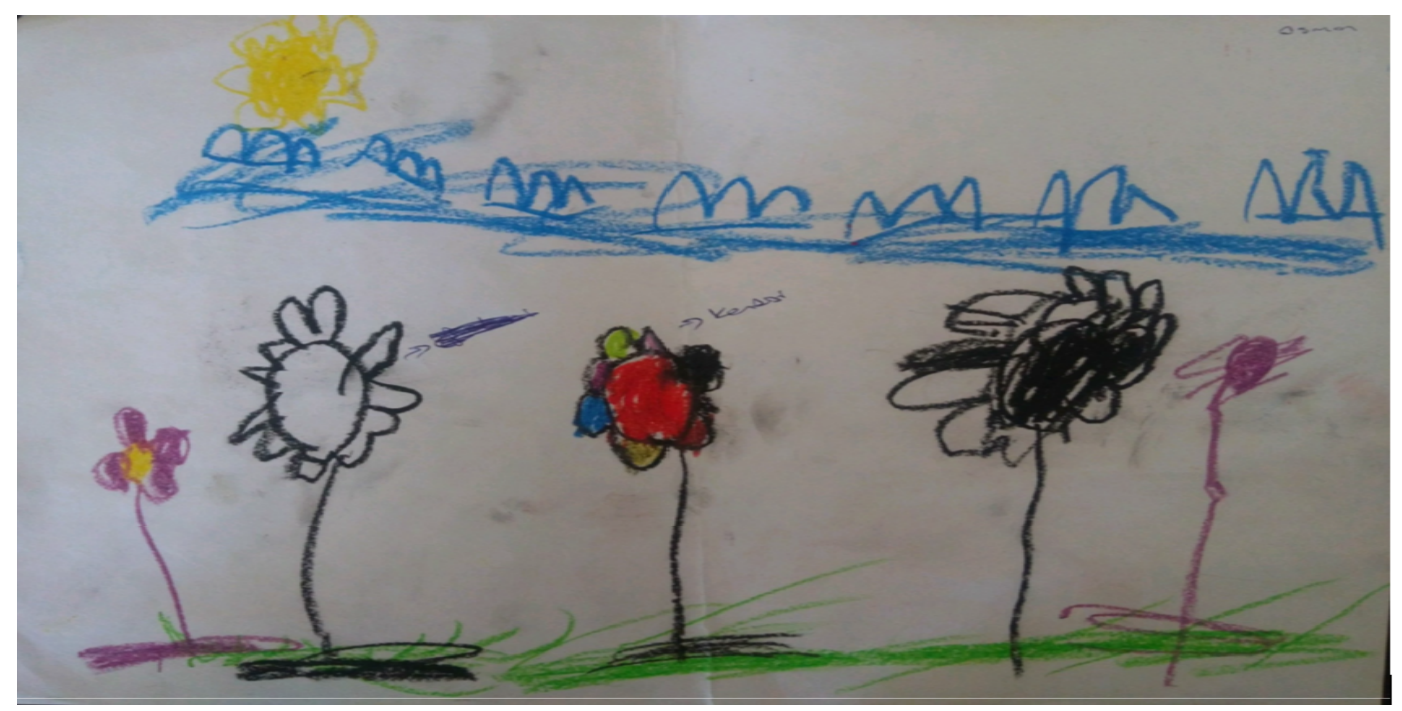

Şekil 5. Baskınlığa yönelik bir resim 
$\mathrm{Bu}$ resim daha önce genel hatları ile tanımlanmaya çalışılmıştır. Resimde ortada olan rengarenk çizilmiş bir çiçek vardır, bu çiçek, resmi çizen çocuğun kendisidir. Yanında bulunan diğer çiçekleri yani arkadaşlarını sade ve tek renkte boyamış; fakat kendisini farklı renkler kullanarak boyamıştır, burada arkadaşlanı arasından baskın olduğunu belirterek dominantlı̆̆ simgelemektedir.

Örnek olarak sunulan iki resimden ilki bask1 altında olan çocuğu ikinci resim ise baskın olan çocuğu göstermektedir. Yapılan analizlerde bireylerin sözlü olarak durumu ifade etmeseler de çizdikleri resimlerle içsel durumlanı ortaya koyduklanı görülmektedir.

Resimde ortada bulunan çiçek çocuğun kendisi ve diğer çiçeklerde arkadaşlarıdır. Çocuğun tamamen kendisini farklı renklere boyamış olması ve dikkatli bir şekilde taşırmadan, belirli boyutlarda özenle çiçeği çizip, boyamış olması mükemmeliyetçiliğini göstermektedir.

\section{Mükemmeliyetçi Resimler}

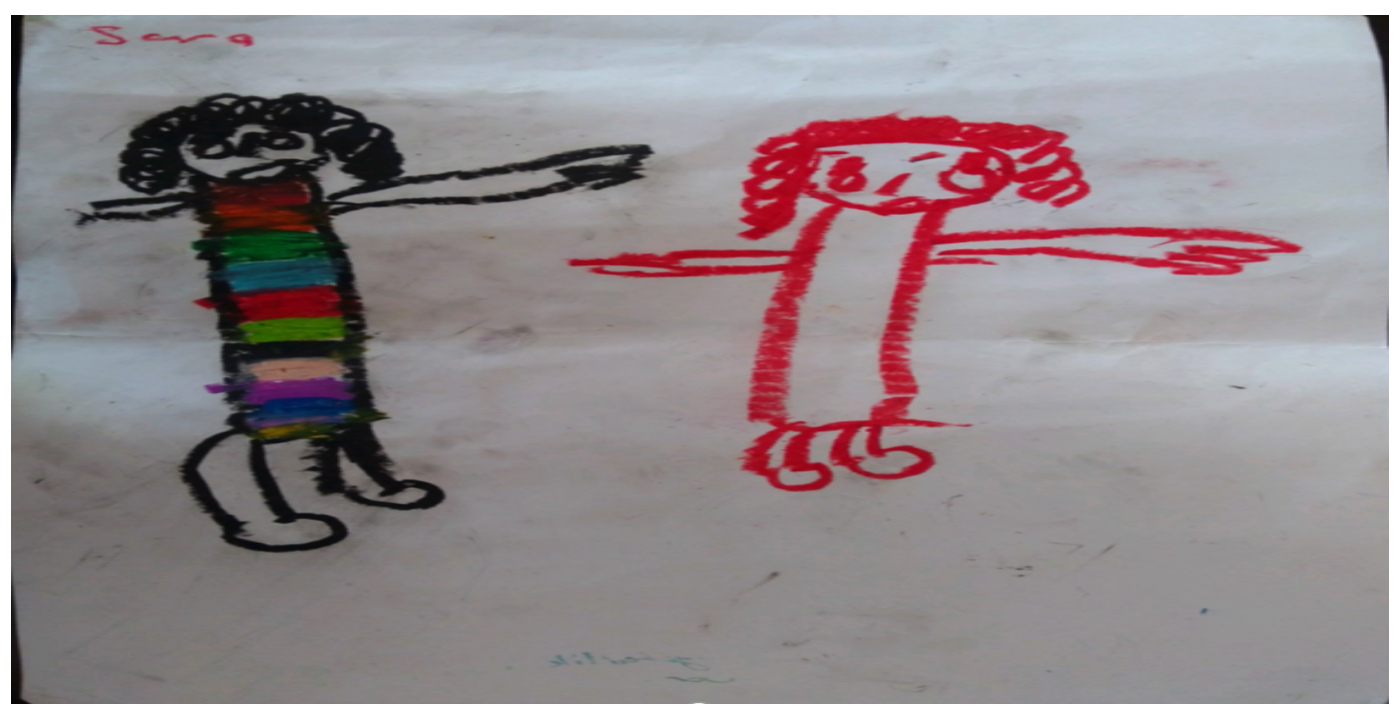

Şekil 6. Mükemmeliyetçiliğe yönelik bir çizim

Resimde iki çocuk gözükmektedir. Soldaki çocuk renkli bir elbiseye sahiptir. Solda bulunan çocuk ise tek renk olacak şekilde çizilmiştir. Ayrıca sol tarafta bulunan çocuk sağdaki çocuktan daha büyüktür. Resimde en başta çizilen siyah saçlı çocuk, resmi çizen çocuğun kendisi olduğunu söylemiştir. Çocuk; kendi elbisesini belli bir düzen halinde, belli bir sırada, farklı renklere boyamıs olması mükemmeliyetçiliğini göstermektedir.

\section{İçine Kapanıklık Olan Resimler}

Öğrencilere verilen yönergede okullarını çizmeleri istenmiştir. Okul kavramsal olarak ifade edilse de öğrenciden çizmesi beklenen imgeler; okul binası, öğrenciler ve öğretmenlerdir. çizilmesi beklenen imgelere ek olarak okul çevresinin güneş, dağ gibi imgelerin yer alaması da muhtemel beklentiler arasındadır. Bu belirtilen imgelerden bir kaçının eksik olması psikolojik bir sorun olarak algılanması gerektiği uzman tarafından ifade edilmiştir. Aşağıda içe kapanıklığa yönelik iki çizim yer almaktadır. 


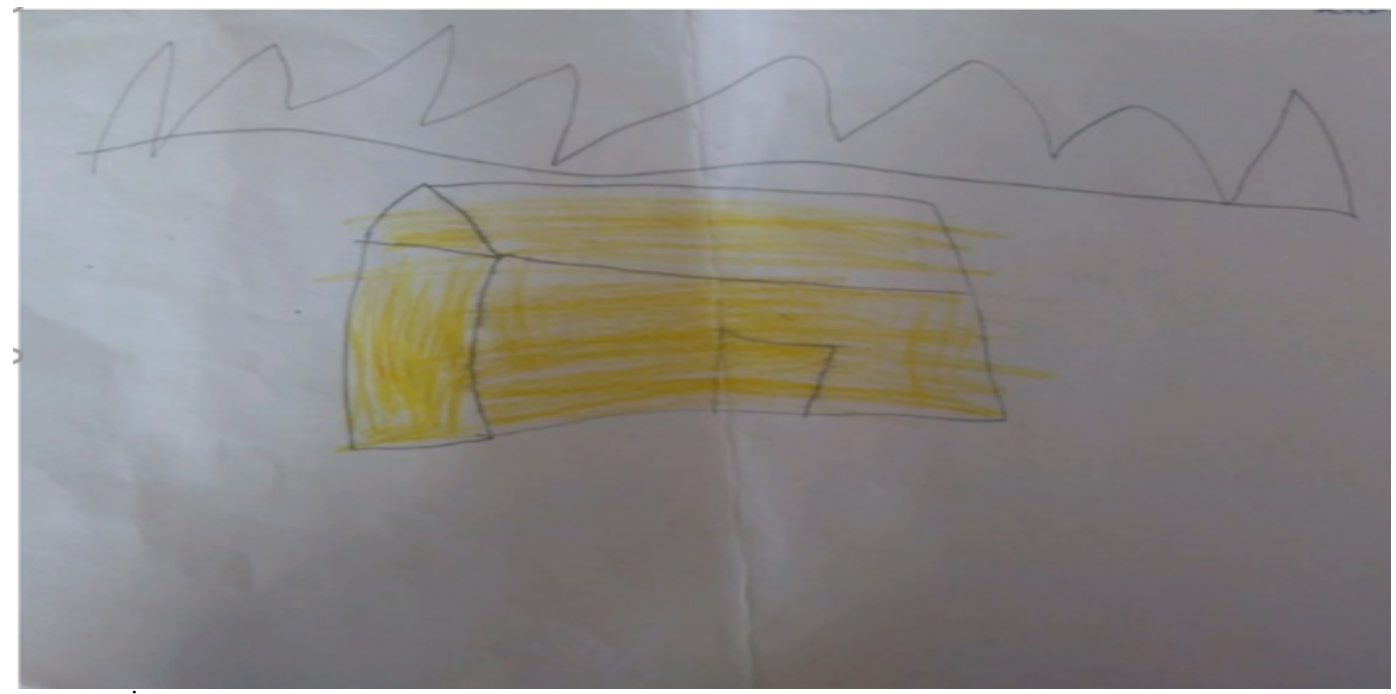

Şekil 7. İçe kapanıklığa yönelik bir çizim

Daha önce bu resme yönelik yorum farklı bir boyutta değerlendirilmiştir. Okul binası penceresiz bir şekilde çizilirken, Resimde çocuğun kendisini, arkadaşlarını ve öğretmenini çizmemiş olması sadece okulun binasını çizmesi, çocuğun çevreyle ilişkisinde içine kapanık olduğunu göstermektedir. Yani çocuğun dış çevreyle iletişim kurmakta sıkıntı çektiğini göstermektedir.

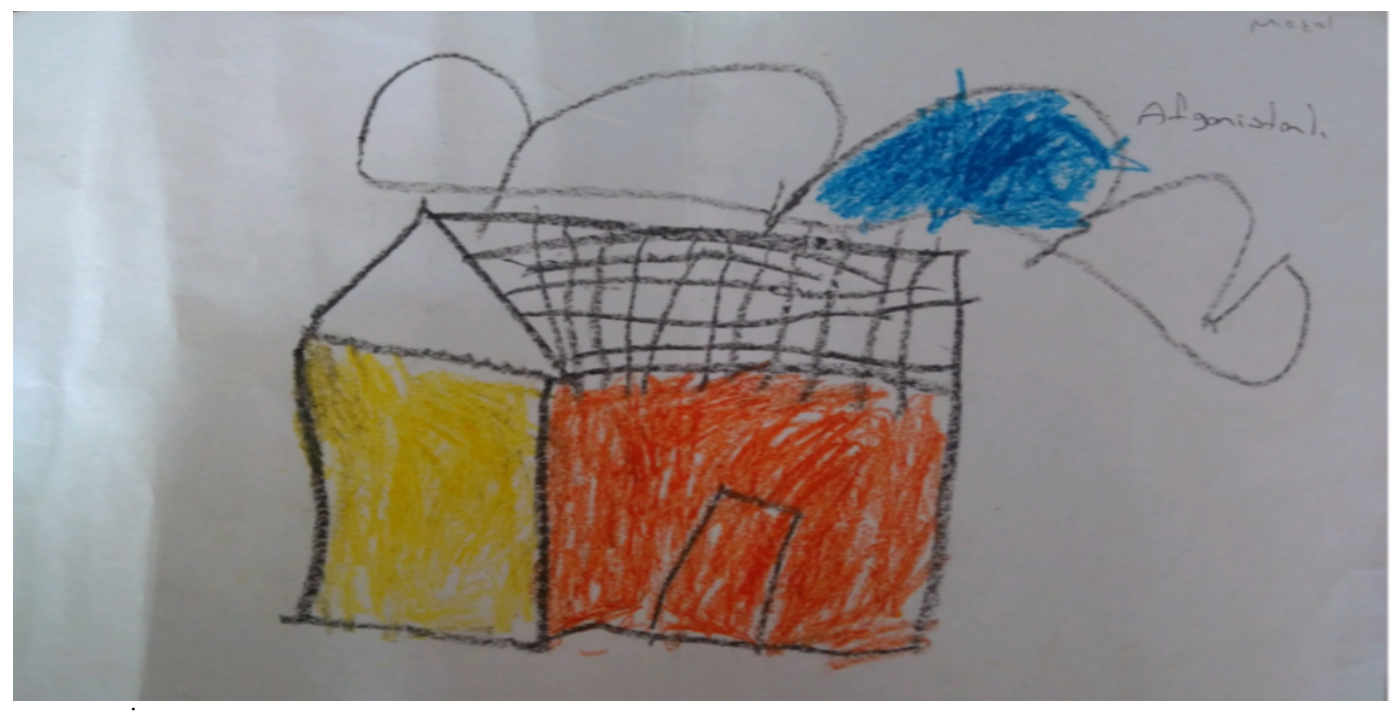

Şekil 8. İçe kapanıklığa yönelik bir çizim

Resimde çizilmiş bir okul vardır; fakat bir önceki resim ile benzer şekilde okulun pencerelerinin olmayışı, çocuğun güven problemine işaret etmektedir. Yukardaki resim ile benzer şekilde kendini ve arkadaşlarını çizmemesi çevreyle olan ilişkisinde de yine içine kapanık olduğunu belirtmektedir. Yukarda görülen örneklerde güven probleminin içe kapanık ile ilişkili olduğu görülmektedir. 


\section{Kızgınlık Olan Resim}

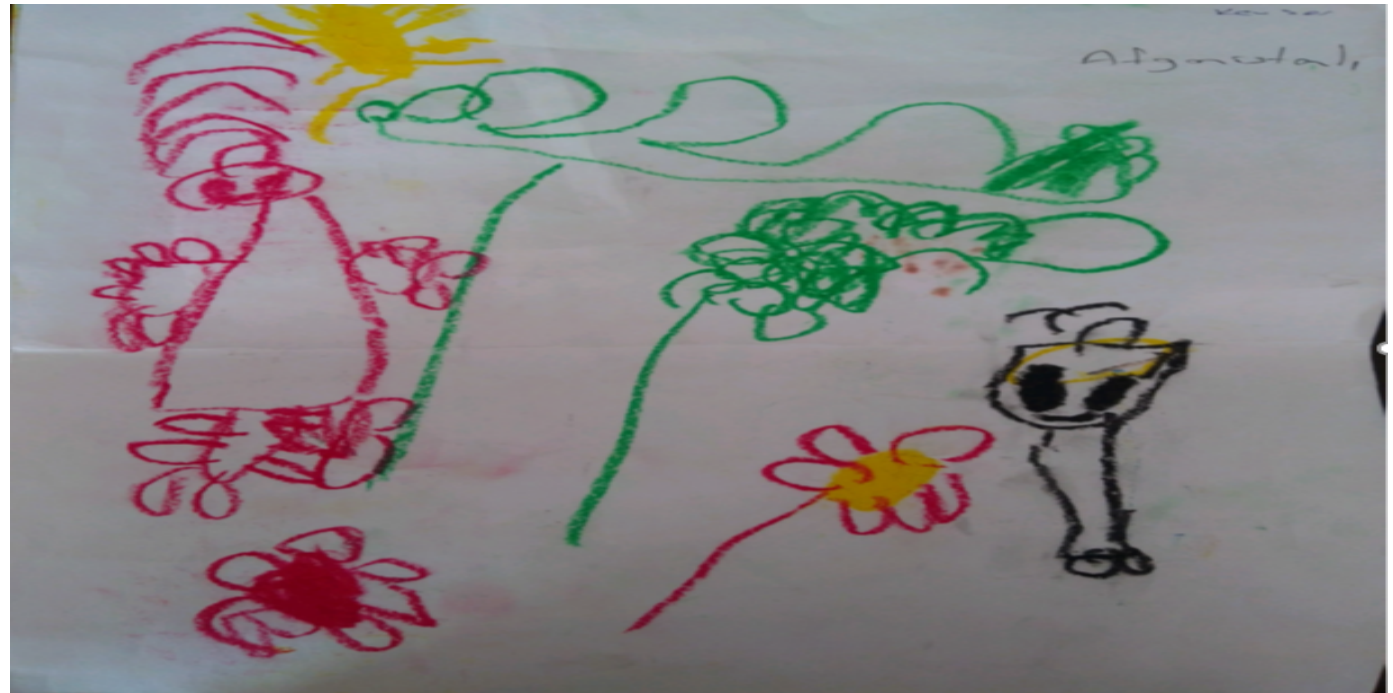

Şekil 9. Kızgınlık ile ilgili çizim

Bu resim daha önce yorumlanmış olmasına karşın yalnızca çocuklara dikkat çekilmiştir. Resimde kırmızı renkte çizilen çocuk, resmi çizen çocuğun kendisidir. Siyah renkte çizilmiş olan çocuk ise arkadaşıdır. Fakat iki arkadaş arasında bulunan çiçekler ve özellikle büyük bir şekilde çizilmiş ağaç figürü arkadaşlar arasında sorunların olduğunu ve araya bazı olayların girdiğini göstermektedir. Daha önce yapılan yorum ile ilişkilendirilince çocuğun arkadaşı tarafından baskılandığı diğer çocuğu baskıcı olarak algıladığı, yaşanan sorunun çocuklar arasında bir gerilime sebep olup öğrencileri birbirinden uzaklaştırdığ1 yorumlanabilir. Buna karşın baskılanan çocuk diğer arkadaşıyla birlikte olma arzusu içinde olduğu fakat yaşanan durumun kızgınlı̆ga sebep olduğu sonucu çıarılabilir.

\section{Mutluluk İfadeli Resimler}

Yapılan çizimlerde çocuklann mutluluklarını ifade ederken bazı sorunlar ile belirttiği görülmüştür. Bu yaşanan sorunlar deprem ve göç gibi kritik durumlar olsa da çocuklar mutlu olduklarını ifade etmektedir. Aşağıda bu duruma yönelik iki örnek sunulmuştur.

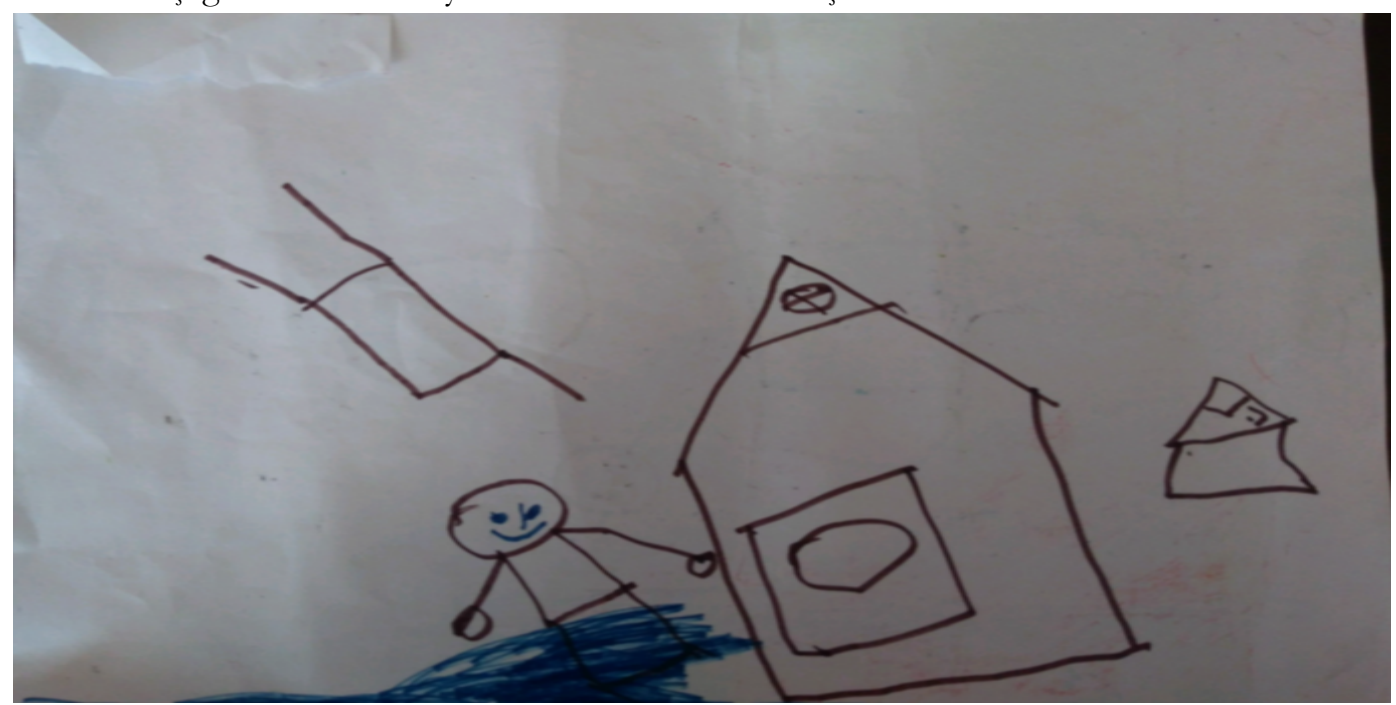

Şekil 10. Mutluluğa yönelik bir çizim

Bu resmi çizen çocuğa," Resimde ne çizdin anlatır mısın?" diye sorulduğunda çocuk, "Zelzele" cevabını vermiştir. Göç öncesinde çocuğun yaşadığı coğrafyada meydana gelen deprem nedeniyle evlerin yıkıldığını betimlemeye çalışığı görülmektedir. Çocuk binaları siyah çizerken yüzünü siyaha göre sıcak bir renk olan mavi ile çizmiştir. Çocuk, her ne kadar depremi yaşayıp çizmiş olsa da, yüzünden gülücükleri 
eksik etmemesi, resimde de kendisini güler yüzlü çizmesi her şekilde mutlu olduğunun göstergesidir. Buna karşın yaşanan deprem çocuğa verilen yönergenin dışına çıkıp hayatında kalıcı iz bırakan depremi çizmesine neden olmuştur. Bu resimde ayrıca karamsarllk ve korku temsil eden renk olan siyah baskın olarak kullanılmıştır.

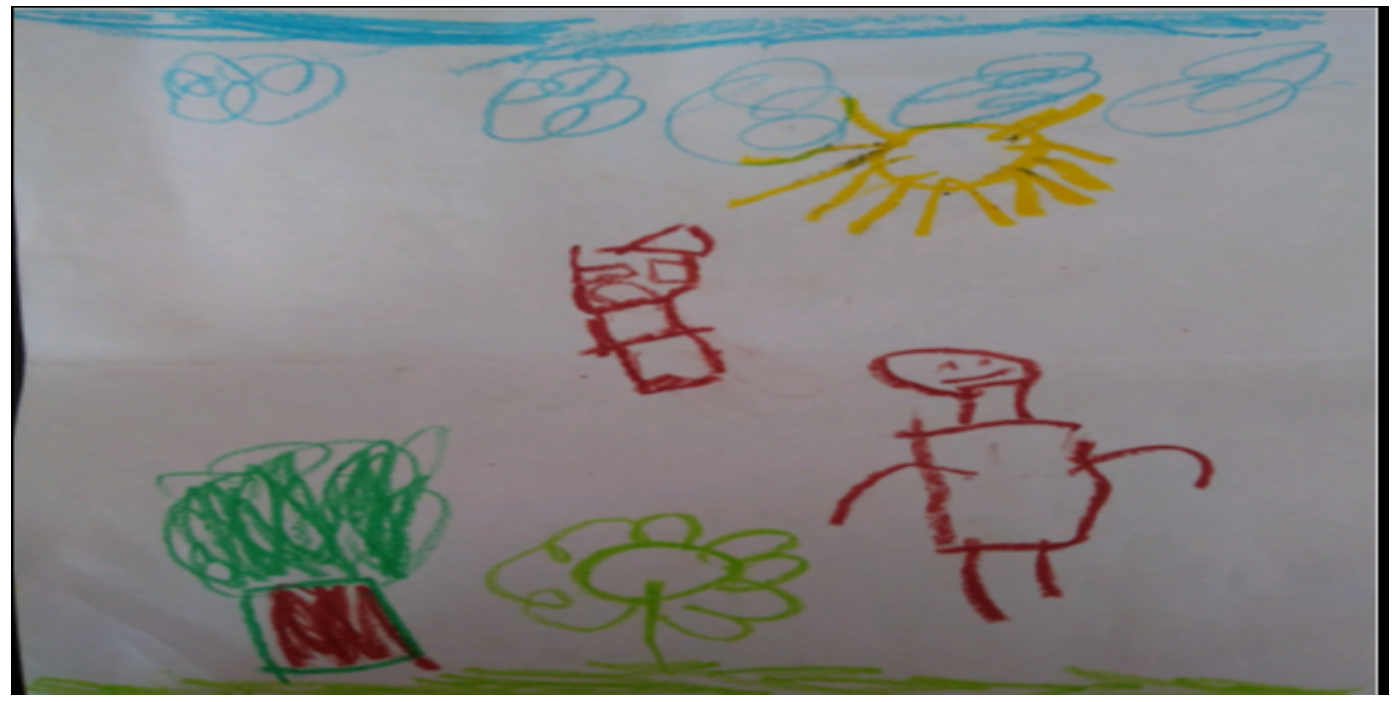

Şekil 11. Mutluluık ile ilgili bir çizim

$\mathrm{Bu}$ resimde her ne kadar çocuk kendisini zemine oturtmamış, güven eksikliği yaşamış olsa da, hayat dair gülebildiğini ve mutlu olduğunu resimde göstermiştir.

Yukarıda verilen örneklerde görüldüğü gibi çocukların yaşanan sorunlara rağmen mutluluklarını ifade ettikleri görülmektedir.

\section{Mülteci kökenli öğrencilerde ortaya çıkan temel sorunlar}

Yapılan analiz sonuçlarında öğrencilerden görülen sorunlar şekil 1'de yer almaktadır. Burada "N" kişi sayısını ifade etmektedir.

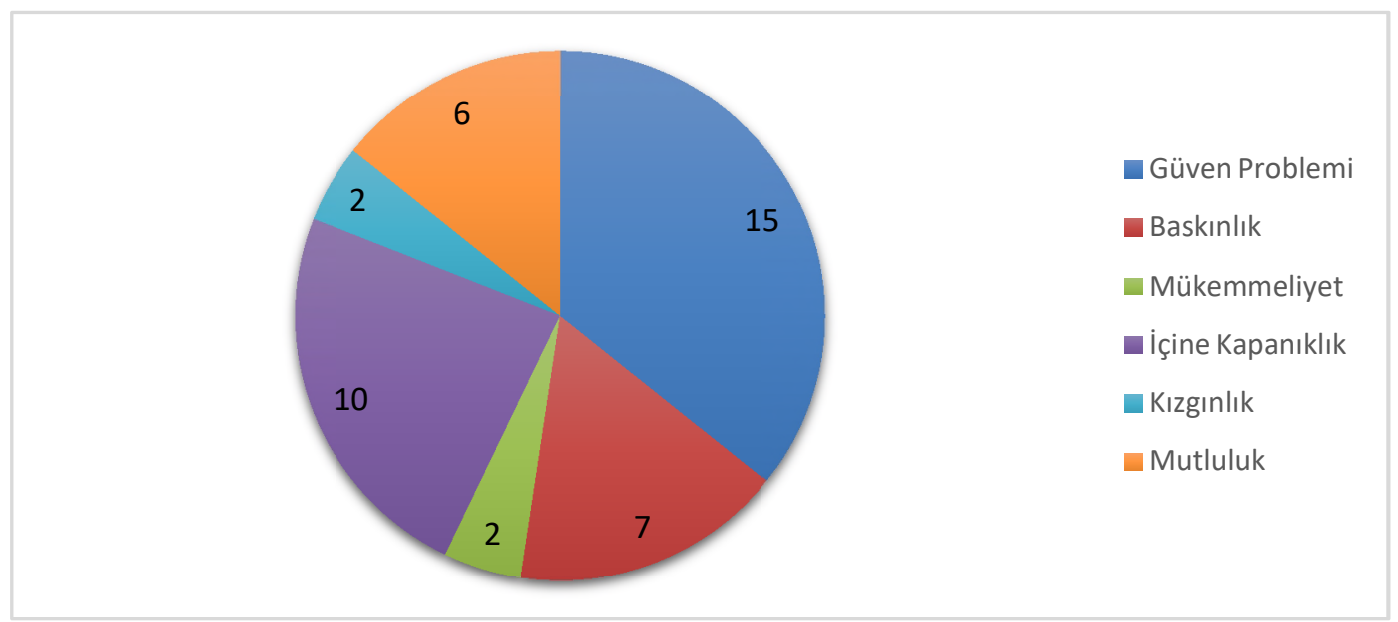

Şekil 1 de görüldüğ̈̈ üzere çizilen resimler sonucunda en çok güven probleminin yaşandığı (f: 15; \%36) gözlemlenmiştir. Bunu takiben içine kapanıklık (f:10; \%24), baskınlık (dominantlık), mutluluk, mükemmeliyet ve kızgınlık görülmektedir. Olumlu durum olarak mutluluk sadece altı öğrencide görülmüştür. Elde edilen kodlar arasında iki resimde kızgnnlık ve mükemmeliyet duygusuna rastlanmıştır. Kızgınlık ve baskınlık kodları elde edilen resimler aynı iki resimdir. 


\section{Sonuç ve Öneriler}

Araştırma katılımcıları olan mülteci kökenli öğrencilerin yaptıklanı resimler yoluyla okula uyum durmalarının belirlenmeye çalışıldığı bu araştırmada, olumsuz duyguların ağırlıkta olduğu görülmektedir. Araştırmaya katılan 24 öğrenciden elde edilen kodlardan yalnızca altı (\%14) tanesinin mutluluk duygusunu ifade eden görsellere yer verildiği görülmüştür. Bu durum Uğurlu, (2018) çalışmasıyla benzerlik göstermektedir. Göç sonucunda oluşan olumsuz koşulların bireylerin hayata karşı tutumlarında olumsuz etkilediği düşünülmektedir. Uzun ve Bütün (2016); Walter, 2007; Yılmaz, (2014) bu durumun altında yatan sebepleri, dil sorunu, halkın genel tutumları olarak ifade etmektedir.

Öğrencilerin resimleri yaparken karamsarlık ve korkuları temsil eden renklerin ağırlıkta kullanıldığ görülmüştür. Bu durumun çocukların çoğunun iç dünyalarında karmaşalar ve korkular yaşadıklarını gösterdiği söylenebilir. Aydın, Şahin ve Akay (2017) göç beraberinde getirdiği mülteciliğin en çok etkilediği grubun çocuklar olduğunu ifade etmektedir. Bu bakımdan çocukların yaşadıkları travmaları resimlerine yansıtmalanı olağan bir durum olarak görülmektedir. Araştrmada kullanılan çiz-anlat tekniği ile çocukların resimlerinde yaşadıkları deprem vb. Durumları anlattıkları görülmüştür.

Resimlerde, çocukların tamamına yakını yalnızca kendilerini çizmiş olup bu durum kendilerini dış dünyadan soyutladıklarını gösterdiği söylenebilir. Bu durum Altıntaş (2016), Başar Akan ve Çiftçi (2018) Fazel, Stein (2002) Dış dünyadan soyutlamanın altında yatan sebep olarak farklı dil ve kültürel unsurlara sahip bir ülkeye göç etmek zorunda kalmalarının sebep olduğu düşünülmektedir.

Yapılan analizlerde güven sorunu belirlenen bir diğer problemdir. Bu durum alanyazında yer alan diğer araştırmalarla desteklenmektedir (Janssen, Bakker, Bosman, Rosenberg ve Leseman, 2012; Perreira ve Ornelas, 2011). Güven sorunun temelinde sosyal statünün düşük olması, sosyoekonomik dur ve azınlık olma duygusu gibi nedenlerin yer aldığı düşünülmektedir.

Örnek olarak sunulan resimlerde birçok olumsuz durumun bir arada olduğu yani bir resimde yalnızca bir olumsuzluğun olmadığ1 görülmektedir. Bu durum normal karşılanmaktadır. Alan yazında duygusal problemlerin birbirlerini tetiklediğine yönelik bir çok araştırma bulunmaktadır. Çizilen resimlerin çoğunda çocukların okula uyum konusunda sorun yaşadığı çizilen resimlerde arkadaşlarına yer vermemelerinden, okulu tam tasvir etmemelerinden başka deyişle özensiz çizmelerinden anlaşılmaktadır (Fazel, Stein 2002; Erdem, 2017;Solu, Kayılı ve Sever, 2020).

Elde edilen sonuçlar doğrultusunda okul öncesi dönemde öğrenim gören çocukların göçün yarattığ travmatik durumların devam ettiği görülmektedir. Bu bağlamda mülteci çocuklar için destekleyici eğitim faaliyetlerinin sağlanmasının önemli olduğu düşünülmektedir. Araştırma grubu Afgan kökenli (Özbek ve Afgan uyruklu) öğrencilerden olmaktadır. Dil açısında Suriye uyruklu öğrencilerden Türkçe bilgisi açısından daha yetkin olduklarında göz önüne alındığında yaşanan travmaların diğer mülteci çocuklarda daha yoğun olduğu düşünülmektedir. Bu bağlamda mülteci öğrenciler için dil eğitim programı ve Türkiye uyum programının hazırlanmasının önemli olduğu düşünülmektedir.

\section{Atıf için (How to cite)}

Karabulut, R., Türksoy, E., Kasapoğlu, N. ve Kırat, H. (2020). Mülteci Çocukların Çizdiği Resimler Yardımıyla Okula Uyum Durumlarının İncelenmesi. Çocuk ve Gelişim Dergisi, 3(6), 38-50. 


\section{Kaynakça}

Altıntaş, S. (2014). Davetsiz misafirler: Türkiye'deki mültecilerin madeniyet görünümleri. İdeal Kent-Kent Araștormalar Dergisi, 14, 252-276.

Başar, M., Akan, D., \& Çiftçi, M. (2018). Learning-teaching process issues in classrooms with refugee students. Kastamonu Education Joumal, 26(5), 1571-1578.

Bekir, H., Aydın, R., Başbuğa, S. (2016).Türkiye’ye Göç Eden Suriyeli Erken Çocukluk Dönemindeki Çocukların Dil Sorunları. I. Uluslararası Göç ve Kültür Sempozyumu, 01-03 Aralık, Amasya.

Dizman H, Gültekin G, Akyol A (2005). Çocukları tanımada resimlerin önemi, Adli Psikiyatri Dergisi,2(2),23-30.

Drawings. http://www.ipt-forensics.com/library/images5.htm.Erișim:28.02.2005.

Driessnack, M. (2006). Draw-and-tell conversations with children about fear. Qualitative Health Research, 16(10), 1414-1435.

Drisko, J. W., \& Maschi, T. (2015). Content analysis. Pocket Guides to Social Work R. NY: Oxford universty press

Erdem, C. (2017). Sınıfinda mülteci öğrenci bulunan sınıf öğretmenlerinin yaşadıkları öğretimsel sorunlar ve çözüme dair önerileri. Medeniyet Eğitim Araştırmalar Dergisi, 1(1), 26-42.

Fazel, M., \& Stein, A. (2002). The mental health of refugee children. Archives of disease in childhood, 87(5), 366-370.

Gelişim Süreçlerinde Çocuk Resminin Yeri, Görkem Kutluer, Ebev Akademi dergisi, sayı 19,2015

Gültekin, D., Bekir, H., Aydın, R. (2016). Suriye Mültecilerin 6 Yaş Çocuklanında Aile Alg1sı.II. Uluslararası Uygulamalı Bilimler Kongresi, 23-25 Eylül 2016, Konya.

Janssen, M., Bakker, J. T., Bosman, A. M., Rosenberg, K., \& Leseman, P. P. (2012). Differential trust between parents and teachers of children from low-income and immigrant backgrounds. Educational Studies, 38(4), 383-396.

Halmatov, S. (2018). Çocuk resimleri analizi ve psikolojik resim testleri çocuklar ve yetişkinler için. Ankara: Pegem.

Kutluer, G. (2015). Gelişim süreçlerinde çocuk resminin yeri. Ekev Akademi Dergisi, 19 (63), 403-410.

Perreira, K. M., \& Ornelas, I. J. (2011). The physical and psychological well-being of immigrant children. The Future of Children, 195-218.

Üstün Memiş, C. (2014). Okul öncesi eğitimde resmin önemi (Master's thesis). İstanbul Arel Üniversitesi Sosyal Bilimler Enstitüsü.

Özlü, K. A. (2015). Çocuklann Hastaneye Yatmaya Bağlı Gelişen Kaygı Düzeylerinin Resim Çizme Yöntemiyle İncelenmesi Yüksek Lisans Tezi. Ankara: Hacettepe Üniversitesi.

Soylu, A., Kaysıll, A., \& Sever, M. (2020). Mülteci çocuklar ve okula uyum: öğretmenlerin kültüre duyarllıkları üzerinden bir çözümleme. Eğitim ve Bilim, 45(201).

Soyupak Yalçınkaya, A. (2020) ortaokul (6.7. Ve 8. Sınıf) öğrencilerinin görsel sanatlar dersine yönelik sahip oldukları metaforlanın çizdikleri resimler yoluyla incelenmesi. (Yayımlanmış yüksek lisans tezi) Pamukkale Üniversitesi Eğitim Bilimleri Enstitüsü Güzel Sanatlar Eğitimi Anabilimdalı. Denizli. 
Sewell, K. (2011). Researching sensitive issues: a critical appraisal of 'draw-and-write' as a data collection technique in eliciting children's perceptions. International Journal of Research \& Method in Education, 34(2), 175-191. DOI: 10.1080/1743727X.2011.578820

Uğurlu, Z. (2018). Suriyeli sığınmacı öğrencilerin okula uyum sorunlarının çözülmesi ve desteklenmesinde öğretmen etkisi. Zorunlu Gögler, 185.

Uzun, E. M., \& Bütün, E. (2016). Okul öncesi eğitim kurumlanındaki Suriyeli sığınmacı çocukların karşılaştıkları sorunlar hakkında öğretmen görüşleri. Uluslararası Erken Cocukluk. Eğitimi Calısmalar Dergisi, 1(1).

Yıldıım, A. Ve Şimşek, H. (2018). Sosyal Bilimlerde Nitel Araştırma Yöntemleri. Ankara: Sekin yayıncilik

Watters, C. (2007). Refugee children: Towards the next horizon. Routledge.

Yilmaz, A. (2014). Uluslararası Göç: Çeşitleri, Nedenleri ve Etkileri. Electronic Turkish Studies, 9(2).

Resimler \& Çocuk Seda Atasoy Mayıs

http://dergipark.gov.tr/download/article-file/453943

www.doktorsitesi.com

www.psikoloji portakalı.com

www.rehberlikservisi.net 